\title{
Dispositivos institucionais filantrópicos e socioeducativos de atenção à infância na assistência social
}

\author{
Institutional philanthropic and socioeducative \\ mechanisms of childcare in the social care
}

\author{
Silvio José BENELLI ${ }^{1}$ \\ Abílio da COSTA-ROSA
}

\begin{abstract}
Resumo
Estudou-se a Assistência Social como instituição que faz dispositivos de produção de subjetividade na atenção à criança e ao adolescente. Para tanto, utilizaram-se algumas coordenadas analíticas conjunturais e estruturais para mapear modelos de atenção assistencial em confronto no campo da Assistência Social. Concluiu-se que haveria dois paradigmas contraditórios, no sentido dialético, organizando a Assistência Social: um seria o modo filantrópico, o outro o modo socioeducativo. Ao primeiro, que é hegemônico no campo, corresponderia uma entidade assistencial ainda organizada a partir de uma atenção filantrópica pautada em uma lógica menorista, articulada por um discurso criminalizante das classes populares, informalmente baseada na noção jurídica da situação irregular, que desenvolveria práticas assistenciais preventivas, repressivas, correcionais e moralizadoras. A construção do modo socioeducativo implica uma atenção socioeducativaque visa à promoção efetiva dos direitos das crianças e dos adolescentes, a partir da sua condição de sujeitos e de cidadãos, por meio de práticas institucionais democráticas, dialógicas, participativas, multiprofissionais e transdisciplinares, fundamentalmente emancipadoras.
\end{abstract}

Unitermos: Análise institucional; Assistência social; Políticas públicas; Psicologia social.

\begin{abstract}
This study investigated Social Care as an institution that creates mechanisms for the production of subjectivity in the care of children and adolescents. For this, we used some analytical coordinates, both conjectural and structural, models of care for mapping care in confrontation in the field of Social Care. It was concluded that there was two contradictory paradigms, in the dialectical sense, organizing social care, one being the philanthropic mode and the other the socioeducative mode. The first, which is hegemonic in the field, corresponds to a care entity still organized from philanthropic care and is guided by a minority age logic, articulated by a discourse of criminalizing the lower classes. It is informally based on the legal concept of irregular situations, which would develop preventive, repressive, correctional and moralizing care practices. The construction of a socioeducative mode implies socioeducative care that aims for an effective increase in the rights of children and adolescents, based on their status as subjects and citizens, through democratic, dialogic, participatory, multi-disciplinary and fundamentally emancipatory institutional practices.
\end{abstract}

Uniterms: Institutional analysis; Social care; Public policies; Social psychology.

$\boldsymbol{\nabla \nabla \nabla \nabla}$

1 Universidade Estadual Paulista "Júlio de Mesquita Filho", Faculdade de Ciências e Letras, Departamento de Psicologia Clínica. Av. Dom Antonio, 2100, Parque Universitário, 19806-900, Assis, SP, Brasil. Correspondência para/Correspondence to: S.J. BENELLI. E-mail: <benelli@assis.unesp.br>.

Artigo elaborado a partir da pesquisa de pós-doutorado de S.J. BENELLI, intitulada "Cartografia das instituições de assistência social a crianças e a adolescentes", Universidade Estadual Paulista "Júlio de Mesquita Filho", 2010. Apoio: Fundação de Amparo à Pesquisa do Estado de São Paulo (Processo 2008/50674-0). 


\section{A interface da Psicologia com a assistência social}

A temática da Assistência Social no cenário brasileiro tornou-se profundamente relevante nas últimas décadas, tendo atingido o estatuto de política pública de Estado (Brasil, 2011; Constantino, 2010; Cruz \& Guareschi, 2009; Gonçalves, 2010; Rodrigues, 2010). Juntamente com a Educação e a Saúde, ela vem se tornando também objeto de interesse da Psicologia, como se pode verificar por uma literatura crescente, tanto por parte de seus órgãos oficiais (Centro de Referência Técnica em Psicologia e Políticas Públicas, 2007, 2009; Conselho Federal de Psicologia, 2010; 2011; Conselho Regional de Psicologia da 6a Região, 2007; Murta \& Marinho, 2009; Silveira, Cobalchini, Menz, Valle \& Barbarini, 2007), quanto por parte de pesquisadores (Alberto, 2008; Barreto, 2011; Benelli \& Costa-Rosa, 2010; Bock, 2004, 2007, 2009; Botarelli, 2008; Constantino, 2010; Cruz \& Guareschi, 2004; Cruz, Hillesheim \& Guareschi, 2005; Dadico \& Souza, 2010; Eidelwein, 2007; Ferreira, 2010; Fontenelle, 2008; Gonçalves, 2010; Lemos, 2007; Paiva \& Yamamoto, 2010; Rogone, 2006; Saliba, 2006; Santana, Doninelli, Frosi \& Koller, 2004; Scarparo, 2008; Senra, 2009; Silva, 2008; Zaniani, 2008).

O campo da Assistência Social circunscreve um conjunto de problemas sociais variados e complexos que demandam a atuação de equipes multiprofissionais para buscar promover seu equacionamento (Conselho Federal de Serviço Social, 2007). Nesse âmbito de trabalho específico, um grande número de alunos de cursos de graduação, bem como de pós-graduação em Psicologia, vêm se engajando em múltiplas atividades de estágio, de pesquisa e de extensão. Além disso, é crescente a contratação de profissionais psicólogos para trabalhar no campo da Assistência Social, atuando em equipamentos institucionais públicos e privados que desenvolvem os mais diversos programas, projetos e serviços assistenciais, nos quais devem prestar serviços psicológicos variados para usuários de todas as idades.

Buscando oferecer uma contribuição para o desenvolvimento científico, técnico, ético e político no âmbito da Psicologia como ciência e profissão, este artigo é derivado de uma pesquisa original que apresenta um caráter crítico e inovador na abordagem do tema da atenção assistencial oferecida a crianças e a adoles-

284 centes considerados em situação pessoal e social de risco (Brasil, 2004; 2005; 2009a), propondo uma análise histórico-conjuntural e lógico-estrutural do campo da Assistência Social, a partir das entidades que oferecem atenção assistencial à infância.

Assim como a política nacional de saúde mental faz dispositivo no contexto mais amplo da política nacional de Saúde Pública, a política nacional de atenção à criança e ao adolescente faz dispositivo no âmbito das demais políticas públicas, tais como as de Educação, de Assistência Social, de Saúde etc., muito embora ela também produza uma legislação específica (Brasil, 1990) e alguns dispositivos próprios (Assis, 2009; Brasil, 2007a; 2007b), buscando articular um sistema de garantias de direitos que funcione em rede.

Como área específica, a Assistência Social possui sua singularidade e complexidades próprias, que nem sempre são conhecidas pelos psicólogos que nela vão trabalhar. A pesquisa realizada permitiu a construção de duas categorias conceituais essenciais: os conceitos de filantropia e de socioeducativo, elaborados na reflexão crítica quando da análise dos dados de campo, bem como da documentação bibliográfica compulsada. Esses dois conceitos fundamentais tornaram possível uma organização científica rigorosa do pensamento, permitindo a elaboração de um texto dotado de uma estrutura teórica sólida, com apresentação de informações fundamentais, de conceitos precisos e objetivos, configurando um mapa que permite situar-se com certa clareza no campo.

A publicação deste artigo se justifica por sua relevância acadêmica, pois apresenta uma abordagem original de uma temática cada vez mais importante para o contexto da Psicologia como ciência e como profissão, oferecendo análises que poderão contribuir para orientar a formação, a pesquisa e a ação profissional de psicólogos inseridos no campo da Assistência Social. Sua relevância social se depreende da contribuição que representa na discussão de aspectos essenciais da atual interface Psicologia e Assistência Social, bem como na indicação de possíveis pistas para o equacionamento de um problema nacional de primeira ordem: a construção de uma cultura de cidadania e de direitos integrais para crianças e adolescentes pobres. Nesse sentido, tanto a pesquisa realizada quanto o artigo dela derivado se pautaram rigorosamente pela opção ética que a Psicologia adotou no cenário brasileiro atual: o compro- 
misso social implicado na promoção e no fortalecimento de processos de transformação social da realidade (Bock, 2009; Conselho Federal de Psicologia, 2011; Gonçalves, 2010).

\section{Mapeando o campo da assistência social}

Quais seriam os modos paradigmáticos de funcionamento da instituição da Assistência Social como política pública na atualidade? Como tais modos de produção de realidade social incidiriam nos dispositivos instaurados por essa instituição social? Quais seriam seus efeitos na organização das entidades assistenciais ditas socioeducativas que atendem a crianças e adolescentes pobres? Para responder a essas questões, realizou-se uma investigação participante no campo de análise constituído pela Assistência Social como instituição que faz dispositivos e também no âmbito das políticas públicas para a criança e o adolescente, num município de médio porte do interior do Estado de São Paulo. O que se pretende é fornecer uma perspectiva estratégica para os psicólogos que atuam no campo da Assistência Social, de modo que possam desenvolver uma atuação informada, contextualizada e avisada sobre a problemática central que perpassa a área. Essa investigação foi aprovada pelo Comitê de Ética em Pesquisa da Faculdade de Ciências e Letras da Universidade Estadual Paulista "Júlio de Mesquita Filho" (Unesp), campus de Assis (SP), Protocolo n 030/2008, em 30 de outubro de 2008, e todos os participantes assinaram um Termo de Consentimento Livre e Esclarecido antes de sua inclusão na pesquisa.

Exerceu-se um longo mandato como conselheiro municipal participando de 23 reuniões de trabalho do Conselho Municipal dos Direitos da Criança e do Adolescente (CMDCA) e de 21 reuniões do Conselho Municipal de Assistência Social (CMAS) no ano de 2008, bem como de diversas atividades, tais como visitas a entidades e organização e participação em diversos eventos na área. No ano de 2009, participou-se de 22 reuniões do CMDCA e de 21 reuniões do CMAS, sendo que também se colaborou com a organização e a realização das Conferências Municipais dos Direitos da Criança e do Adolescente e da Conferência Municipal de Assistência Social. No ano de 2010, participou-se de 15 reuniões de trabalho do CMDCA e de 17 reuniões do
CMAS. Nos anos de 2009 e 2010 também foram realizados trabalhos de supervisão institucional em entidades assistenciais e em um Centro de Referência Especializado da Assistência Social (CREAS). Toda essa rica experiência de imersão institucional no campo da Assistência Social e de um conjunto composto por 25 entidades assistenciais que atendem a crianças e adolescentes considerados em situação pessoal e social de risco, num processo de participação observante, foi acompanhada de um intenso trabalho de apropriação da literatura pertinente, bem como de reflexão, de análise e de escrita. A perspectiva de estudo adotada pautou-se pelos operadores da Análise Institucional (Baremblitt, 1998; Barus-Michel, 2004; Benelli, 2004, 2009; Donzelot, 2001; Foucault, 1999; Goffman, 1987; Lourau, 1995). Para a análise e interpretação dos dados da pesquisa também se operou com quatro categorias de análise histórico-conjuntural propostas por Amarante (1995) para mapear modelos de atenção psicossocial e, ainda, com uma grade analítica de base lógico-histórica e de inspiração marxista dialética, desenvolvida por Costa-Rosa (2000; 2011), instrumental de análise institucional que pode ser utilizado para mapear paradigmas contraditórios em um determinado campo de análise.

\section{Análise institucional dos modos de produção de subjetividade}

Costa-Rosa (2011) tem-se ocupado com a pesquisa e a discussão das práticas de atenção em Saúde Mental contemporânea, procurando colaborar na criação e na contraposição de experiências alternativas ao hospital psiquiátrico e ao modelo de suas práticas. Sua tese é de que há dois modos básicos de práticas em saúde mental no contexto atual: o modo asilar e o modo psicossocial. Propõe ainda o modo psicossocial como um paradigma das práticas substitutivas ao modo asilar. A elaboração das práticas do modo psicossocial emerge a partir de diversos movimentos sociais e científicos e de vários campos teóricos: análise política das instituições, análise institucional, teoria psicanalítica da constituição subjetiva e elementos de análise histórica dos principais movimentos na área de saúde mental. É de uma síntese de sua teoria que se partiu para a elaboração deste estudo. Aplicou-se seu instrumental teórico e analítico para pensar a Assistência Social como 
instituição e também como dispositivo de produção de subjetividade.

Em sua gênese, uma instituição pode ser entendida como sendo "o agenciamento das pulsações da demanda social (falta em sentido amplo que emerge dos conflitos e oposições presentes no espaço social), mediadas pelo imaginário (conjunto de imagens ideais) e a ideologia (representações sociais)" (Costa-Rosa, 2011, p.46), numa conjuntura que pode ser compreendida por meio do conceito de Processo de Estratégia de Hegemonia (PEH) (linhas de composição das Formações Sociais em termos das pulsações que as organizam e que nelas se atualizam) (Costa-Rosa, 2011). Portanto, trata-se de entender as instituições como produção da ação social coletiva no contexto sócio-histórico no qual elas emergem e funcionam, na interação entre saberes e poderes, produzindo sujeitos, subjetividades diversas, inclusive em suas diferentes modalizações (Costa-Rosa, 2000).

A sociedade capitalista caracteriza-se por uma divisão que se polariza em dois blocos conflitantes: um polo dominante e outro subordinado. O PEH é a forma estratégica pela qual o movimento social coletivo procura manter o equilíbrio dinâmico da sociedade (Costa-Rosa, 2011). O polo dominante articula um conjunto de práticas produtoras de efeitos repressivos e ideológicos, além de um conjunto de concessões táticas, seguidas de sua recuperação: cede os anéis para não perder os dedos, como diz o ditado popular e, mais tarde, procura retomá-los. Já o polo subordinado desenvolve um conjunto de práticas que, por um lado, o identificam de modo alienado com o polo dominante; por outro, possui um conjunto próprio de interesses específicos (que podem apresentar-se de modo passivo e inclusive inadvertido). Além disso, também desenvolve várias práticas alternativas que, algumas vezes, chegam a aspirar à elaboração de uma hegemonia dos interesses subordinados, em contraposição à dominante, então vigente.

A consistência de uma instituição é dada pela articulação de saberes e de práticas, mediante um discurso lacunar (Costa-Rosa, 2011). O saber institucional justifica a ação, a prática coletiva que institui a própria vida no contexto institucional, criando todos os seus habitantes e estabelecendo suas funções. Mas as instituições fazem mais do que expressam seus estatutos, e também fazem menos, pois possuem funções positivas e negativas. O saber busca racionalizar e tornar plausível a existência da instituição, produzindo um discurso lacunar, esburacado, que tenta recobrir a prática concreta, muitas vezes em franca contradição com os objetivos explícitos em função dos quais ela foi criada. Para conhecer realmente uma determinada instituição, é preciso não apenas ouvir os discursos que nela circulam e estudar seus estatutos, mas é necessário prestar atenção naquilo que fazem seus diversos agentes e sua clientela, investigando suas práticas não discursivas.

Baseando-se em Hegel "A ciência da lógica", Costa-Rosa (2000; 2011) afirma que se pode compreender a instituição como a conjunção de momentos articulados: o nível das práticas discursivas (plano lógico) representa o aspecto universal; o nível das práticas não discursivas (plano dos dispositivos: aparelho capaz de realizar determinadas funções), representa o aspecto particular; finalmente, o nível da práxis (plano da articulação do universal e do particular), representa a instituição em sua singularidade. Neste momento da singularidade é que se pode conceber a instituição como dispositivo.

O funcionamento institucional expressa os movimentos diversos de um conjunto segmentar e articulado de pulsações e ações instituintes e efeitos instituídos (Costa-Rosa, 2011). Os diversos atores que emergem no contexto institucional são produtos e produtores dele, movidos por necessidades as mais diferentes. Os interesses segmentares podem ser apreciados num espectro que vai dos simplesmente diferentes até os que são incontestavelmente contraditórios. Toda produção institucional pode ser entendida como produção de subjetividade, de sujeitos produzidos a partir de uma subjetividade serializada ou singularizada.

A instituição consiste, então, em uma formação social instável, amálgama de conflitos múltiplos, de pulsações da demanda social. Ela se desdobra em uma ordem latente e outra manifesta. É imprescindível, portanto, realizar um trabalho de análise, de interpretação do sentido do discurso e das práticas institucionais para não se inserir nelas de um modo funcionalista.

As instituições tendem a explicitar, sobretudo, suas funções positivas em seu discurso institucional, geralmente plasmado em estatutos, regimentos, projetos e normas. Por exemplo, as entidades assistenciais 
afirmam, em seus planos de trabalho, que seus objetivos consistem na proteção, na defesa, na promoção e na educação de crianças e de adolescentes considerados em situação pessoal e social de risco. Mas elas tendem a fazer não apenas isso. Será a análise do discurso que revelará as funções negativas das instituições. Somente uma interpretação desse discurso e das suas relações com o saber e com as práticas possibilitará o acesso às suas funções negativas.

De acordo com Costa-Rosa (2011), as instituições, situadas no contexto sócio-histórico do Modo de Produção Capitalista (MPC), apresentam invariavelmente as seguintes funções negativas: a) Produção de mais-valia, articulando-se com a produção de bens e serviços de outras instituições (no caso das entidades assistenciais, elas consomem alimentos, materiais e serviços pedagógicos, esportivos e educativos etc.); b) Reprodução das relações sociais dominantes: domínio e submissão, subjetividade alienada e serializada (é comum que as práticas educativas nas entidades assistenciais sejam predominantemente autoritárias e repressivas, buscando modelar um comportamento dócil e obediente nas crianças e adolescentes); c) Produção de novas formas de relações sociais que expressam os interesses do polo subordinado, podendo produzir subjetividade singularizada (nas entidades assistenciais podem ser produzidas relações sociais inéditas, a partir de práticas concretas que promovam a participação, a democracia, os direitos sociais, a cidadania efetiva e a transformação social).

A análise das contradições indica o estado dos conflitos que se atualizam e se metabolizam na instituição em relação à demanda social de que ela é o efeito. Para analisar o estado do jogo de forças institucionais é preciso especificar as principais contradições ativas no contexto, distinguir entre contradição principal e contradições secundárias e compreender os antagonismos decorrentes das diferenças essenciais. Analisando a proporção de forças que possui cada um dos polos dos interesses presentes em determinada conjuntura particular, pode-se detectar o índice do estado das contradições.

A partir dessas coordenadas analíticas, procurou-se mapear quais seriam os paradigmas em confronto no campo da Assistência Social como instituição e política pública. Em seguida, tomando um conjunto sin- gular de entidades que compõem essa instituição num dado município do interior do Estado de São Paulo, estudou-se o modo como tais coordenadas paradigmáticas incidem nessas entidades que atendem a crianças e adolescentes que estão vivendo em situação de pobreza, aplicando os parâmetros de Amarante (1995) e também a grade analítica de Costa-Rosa (2000; 2011) nesse âmbito particular da realidade social. Já de partida pode-se supor, a partir das investigações realizadas, que nas entidades assistenciais que atendem a crianças e adolescentes, situadas no contexto sócio-histórico capitalista e no campo da Assistência Social, predomina um paradigma que se pode denominar de modo filantrópico, atraindo com sua força gravitacional os saberes, as práticas, os discursos e a produção de subjetividade nesse campo institucional. Seu oposto dialético seria um paradigma que poderia ser denominado de modo socioeducativo, configurando-se, atualmente, mais como uma possibilidade lógica e estratégica no campo, do que como efetivamente constituído.

\section{Assistência social como instituição e política pública}

Embora não adotando uma perspectiva linear e mecanicista da história, é possível localizar nas práticas de caridade desenvolvidas por grupos religiosos diversos ao longo do tempo um tipo de atendimento aos membros pobres e ditos desvalidos da comunidade: crianças pobres e órfãs, idosos, doentes etc. A filantropia benemerente dos ricos, com seu viés moralizante e profissionalizante dos indivíduos pobres, também foi uma figura histórica importante quanto às práticas sociais relacionadas com os cuidados oferecidos para essa faixa da população. Tais práticas históricas podem ser consideradas eminentemente funcionalistas, não críticas e promotoras de ajustamento e de adaptação social integradora (Benelli, 2010).

As ações do Estado com relação ao que se denomina de questão social, termo que inclui os múltiplos efeitos do funcionamento estrutural do MPC, tais como a pobreza e todo o seu corolário, gerada pelo desemprego, pela exploração e dominação exercidas pela elite sobre a classe trabalhadora e por práticas de exclusão social, podem ser chamadas de políticas públicas. Os 
diversos problemas sociais podem ser capazes de mobilizar os membros da sociedade civil organizada, que passam, também, a pressionar agências estatais, cobrando encaminhamentos e soluções para tais dificuldades.

Quando um determinado problema, no caso, a pobreza e os pobres, alcança o nível de objeto de preocupação e de debate nas instâncias diversas do Estado, tais como as de Segurança Pública, do Legislativo, do Executivo e do Judiciário, dentre outras, as respostas e ações do Estado, relacionadas com tentativas de equacionamento do problema em pauta, podem ser consideradas como sendo políticas públicas. Nesse sentido, políticas públicas são ações do Estado que visam a equacionar determinado problema específico, sendo que normalmente são criados, então, dispositivos institucionais para lidar com esse objeto social: instituições são criadas, leis são formuladas e promulgadas, organizações e estabelecimentos são inventados e instituídos, equipamentos são produzidos e implementados, atores sociais são produzidos e convocados para lidar com esse novo objeto institucional, recortado no campo social, emergindo como uma nova figura social. Desse modo, saberes e discursos, poderes e práticas políticas, ordenamentos jurídicos, profissionais, instrumentos e técnicas de trabalho, figuras sociais novas, sujeitos e objetos são inventados e institucionalizados no campo social, criando novas realidades sociais.

Considerar a Assistência Social (Brasil, 1988; 2004; 2005; 2011) como instituição implica problematizar a constituição de um campo original formado por um conjunto de saberes e de práticas, inseridos num contexto sócio-histórico mais amplo, de ordem político-social, ideológico-jurídica, técnico-científica e ética, que inventam, criam e recortam figuras sociais específicas sobre as quais atuam. A instituição da Assistência Social pode, assim, ser considerada como um dispositivo de produção de subjetividade, sendo atravessada por uma série de outras instituições com as quais faz interface.

O discurso oficial afirma que o Sistema Único de Assistência Social (SUAS) (Brasil, 2005), cujo modelo de gestão pretende ser descentralizado e participativo, constitui-se na regulação e organização em todo o território nacional dos serviços, programas, projetos e benefícios socioassistenciais, de caráter continuado ou 288 eventual, executados e providos por pessoas jurídicas de direito público sob critério universal e lógica de ação em rede hierarquizada e em articulação com iniciativas da sociedade civil. Além disso, diz-se que o SUAS procura definir e organizar os elementos essenciais e imprescindíveis à execução da política pública de Assistência Social, pretendendo alcançar uma normatização de padrões nos serviços (Brasil, 2009a), buscando promover a qualidade no atendimento aos usuários, estabelecendo indicadores de avaliação e de resultados, bem como nomenclatura uniforme para os serviços e a rede prestadora de serviços socioassistenciais, tanto pública quanto privada.

Parece pertinente considerar que, com o SUAS, a instituição da assistência social se torna propriamente política pública no Brasil (2005), fazendo dispositivo. Sem negar as lutas de categorias profissionais específicas em torno da formulação da Assistência Social como política pública de dever do Estado e de direito do cidadão, não se pode deixar de considerar que ela representa, sobretudo, uma concessão estratégica do Estado por meio da qual se procura gerenciar as refrações diversas do problema social, recortando-o em diversos segmentos aos quais se fornecem serviços, projetos, programas e benefícios, mas de modo focalizado e predominantemente paliativo, sem jamais problematizar as causas estruturais que produzem esses problemas sociais. O discurso oficial da Assistência Social é profundamente lacunar, parecendo visar mais a produzir efeitos simbólicos que deem legitimidade ao Estado e ao governo do que a incidir concreta e eficazmente na transformação da realidade.

Enquanto instituição social, a Assistência Social (Brasil, 2004; 2005; 2011) representa uma construção lógica que segue parâmetros semelhantes aos da área da Saúde. Ela trabalha com as noções de níveis diferentes de prevenção e de atenção aos problemas da população, lançando mão de práticas educativas básicas, por meio de orientações e esclarecimentos, disponibilizando informações sobre direitos, legislações, localização de serviços, projetos, programas e benefícios, configurando um conjunto de ações de Atenção Assistencial. O SUAS (Brasil, 2005) estabeleceu níveis primários, secundários e terciários de atendimento e de encaminhamento das demandas sociais, sendo denominados de Proteção Social Básica (PSB) e de Proteção Social Especial (PSE) de média e de alta complexidade. 
A prevenção de situações de risco por intermédio do desenvolvimento de potencialidades e aquisições e o fortalecimento de vínculos familiares e comunitários são os objetivos da PSB do SUAS. Esse nível de proteção é destinado para a população que vive em situação de vulnerabilidade social decorrente da pobreza, privação (ausência de renda, precário ou nulo acesso aos serviços públicos, dentre outros) e/ou fragilização de vínculos afetivos relacionais e de pertencimento social (discriminações etárias, étnicas, de gênero ou por deficiências, dentre outras).

O nível da Proteção Social Básica prevê o desenvolvimento de serviços, programas e projetos locais de acolhimento, convivência e socialização de famílias e de indivíduos, conforme identificação da situação de vulnerabilidade apresentada. Devem incluir as pessoas com deficiência e ser organizados em rede, de modo a inseri-las nas diversas ações ofertadas. Tanto os benefícios de prestação continuada como os eventuais, compõem a PSB dada a natureza de sua realização. O estabelecimento que configura a PSB nos municípios e no Distrito Federal são os Centros de Referência de Assistência Social (CRAS) - (Brasil, 2006a; 2009b). As equipes multidisciplinares de referência dos CRAS devem executar os serviços de proteção social básica e organizar e coordenar a rede prestadora de serviços socioassistenciais locais do SUAS.

O Centro de Referência de Assistência Social (Brasil, 2006a; 2006b; 2009b) é uma unidade pública da política de assistência social de base municipal, integrante do SUAS, localizado em áreas com maiores índices de vulnerabilidade e risco social, destinado à prestação de serviços e programas socioassistenciais no nível de PSB às famílias e indivíduos e à articulação destes serviços no seu território de abrangência, e uma atuação intersetorial na perspectiva de potencializar a proteção social. Algumas ações da proteção social básica devem ser desenvolvidas necessariamente nos CRAS, como o Programa de Atenção Integral às Famílias (PAIF), enquanto outras, mesmo ocorrendo na área de abrangência desses centros, podem ser desenvolvidas fora de seu espaço físico, desde que a eles referenciadas. 0 CRAS também deve organizar a vigilância sobre os processos de exclusão social de sua área de abrangência, em conexão com outros territórios.

A Proteção Social Especial do SUAS (Brasil, 2005) é destinada a famílias e indivíduos que se encontram em situação de risco pessoal e social por ocorrência de abandono, maus tratos físicos e/ou psíquicos, abuso sexual, uso de substâncias psicoativas, cumprimento de medidas socioeducativas, situação de rua e/ou de trabalho infantil, entre outras situações de violação dos direitos. Os serviços de proteção social especial têm estreita interface com o Sistema de Garantia de Direitos, exigindo muitas vezes uma gestão mais complexa e compartilhada com o Poder Judiciário, o Ministério Público e outros órgãos e ações do Executivo. Como se pode notar, a lógica da rede é fundamental, enquanto estratégia técnica de gestão para o bom funcionamento da política de Assistência Social.

No caso da Proteção Social Especial, há dois níveis de complexidade: média e alta. No nível de média complexidade estão incluídos aqueles que oferecem atendimento às famílias e indivíduos com seus direitos violados, mas cujos vínculos familiares e comunitários não foram rompidos. A proteção social de média complexidade é organizada nos Centros de Referência Especializados de Assistência Social (Brasil, 2006c), que são unidades públicas estatais que realizam diversas ações de Atenção Assistencial, tais como acompanhamento de indivíduos e famílias com um ou mais de seus membros em situação de ameaça ou violação de direitos. Seus objetivos consistem em fortalecer as redes sociais de apoio da família; contribuir no combate a estigmas e preconceitos; assegurar proteção social imediata e atendimento interdisciplinar às pessoas em situação de violência visando à sua integridade física, mental e social; prevenir o abandono e a institucionalização; fortalecer os vínculos familiares e a capacidade protetiva da família. Neles, são ofertados serviços socioassistenciais que requerem acompanhamento individual e maior flexibilidade nas soluções protetivas. Da mesma forma, requerem maior estruturação técnico-operacional e atenção especializada e mais individualizada, comportam encaminhamentos monitorados e sistemáticos, apoios e processos que assegurem qualidade na atenção protetiva e efetividade na reinserção almejada. Já os serviços de Proteção Social Especial de Alta Complexidade são aqueles que garantem proteção integral - moradia, alimentação, higienização e trabalho protegido -, para famílias e indivíduos que se encontram sem referência e/ou em situação de ameaça, necessitando ser retirados do convívio familiar e/ou comunitário. 
Além do Centro de Referência de Assistência Social e do Centro de Referência Especializado de Assistência Social, enquanto novos estabelecimentos assistenciais que estão sendo implementados nos municípios brasileiros, ainda existe todo um conjunto constituído pelas denominadas entidades assistenciais e filantrópicas tradicionais privadas. Tais estabelecimentos normalmente foram sendo criados ao longo do tempo por diferentes atores sociais: indivíduos e grupos religiosos, membros da elite local, políticos, empresários e filantropos, visando atender a demandas de crianças, adolescentes, jovens, adultos, gestantes, doentes e idosos pobres. Esse conjunto de entidades históricas, tais como os orfanatos, os asilos, entidades beneficentes e filantrópicas que atendiam a crianças e a adolescentes pobres e a indivíduos pobres de outras idades, foi incluído como parte da rede socioassistencial por meio do vínculo SUAS, acordo por meio do qual todos esses estabelecimentos tiveram que se adequar institucionalmente à Lei Orgânica da Assistência Social (LOAS) (Brasil, 1993; 2011) e também ao Estatuto da Criança e do Adolescente (ECA) (Brasil, 1990), buscando obter certificado de inscrição junto ao Conselho Municipal dos Direitos da Criança e do Adolescente e também do Conselho Municipal de Assistência Social, para assim poder manter suas antigas isenções fiscais junto ao Estado e continuar em funcionamento.

As considerações que se seguem resultam de um conhecimento profundo da realidade das entidades de atendimento socioassistencial à criança e ao adolescente que não cometeram ato infracional, num determinado município do interior do Estado de São Paulo. Essas análises são fruto de um intenso trabalho de elaboração do pensamento, a partir de um amplo conjunto de observações obtidas por meio de uma imersão longa, engajada, operativa e problematizadora nesse campo.

\section{Paradigmas contraditórios no campo da assistência social e na atenção à criança e ao adolescente}

Os termos socioeducativo e socioassistencial têm sido empregados para designar algumas das atividades pretensamente inovadoras que a Assistência Social, enquanto política pública de Estado, tal como definida pelo SUAS (Brasil, 2005), vem procurando implementar no âmbito nacional, sobretudo nos contextos municipais, no atendimento a indivíduos de todas as faixas etárias. Crianças, adolescentes, jovens, adultos e idosos podem ser atores sociais incluídos em diversos projetos, programas e serviços que podem ser qualificados genericamente como sendo socioeducativos ou socioassistenciais. Tanto as ideias quanto as práticas da Assistência Social e da política nacional para a criança e o adolescente, consubstanciadas no ECA, têm sido associadas a esses termos, de acordo com o que indica a literatura oficial (Brasil, 1990; 1993; 2004; 2005;2011).

Será que o termo socioeducativo poderia aspirar a se constituir/instituir como um conceito capaz de designar um tipo de Atenção realmente alternativa à atenção filantrópica, que ainda seria hegemônica no campo da Assistência Social? Afirma-se que, a partir da nova Política Nacional de Assistência Social (PNAS) (Brasil, 2004) e SUAS (Brasil, 2005), a Assistência Social se tornou um direito do cidadão e um dever do Estado. Mas será que a Assistência Social realmente superou sua histórica determinação social enquanto ajuda samaritana, favor, benesse, assistencialismo e tutela? Observa-se que no plano jurídico os discursos são avançados, mas a prática política e técnica, no âmbito municipal, costuma se manifestar avessa ao novo reordenamento institucional proposto, assepsiando-o de suas características mais politizadas, democráticas e participativas e mantendo ações tradicionais e predominantemente tuteladoras.

A atenção psicossocial pode ser considerada um tipo de atuação profissional desenvolvida por profissionais da área de Psicologia - embora não exclusivamente-, envolvendo um conjunto de procedimentos técnicos especializados, com a finalidade de estruturar processos e ações de atendimento a indivíduos e a grupos que procuram por serviços públicos de Assistência Social (Lancetti, 1996), de Saúde e de Saúde Mental (Costa-Rosa, Luzio \& Yasui, 2003), dentre outros. De um modo geral, pode-se considerar a Atenção como uma ação constituída por uma série de elementos técnicos instrumentalizados e empregados por diversos profissionais nos campos da Assistência Social, da Saúde e da Saúde Mental, da Educação etc. Atenção, com inicial maiúscula, designaria, assim, o conjunto de ações realizadas em diversas áreas do campo social, focadas em 
práticas múltiplas, nas quais estariam incluídas as noções de tratamento, cuidado, promoção e, inclusive, atenção.

Há um conjunto de práticas de Atenção orientadas por perspectivas teóricas, técnicas, éticas e políticas encontradas no campo das abordagens psicossociais (Vasconcelos, 2008a; 2008b; 2009) que precisam ser explicitadas, configurando propriamente o que se denomina de atendimento psicossocial, que é oferecido por uma equipe profissional multidisciplinar. Atendimento significa ato ou prática de atender; remete à oferta de uma atenção sistemática para o sujeito que procura por um determinado serviço público. Inclui o conjunto organizado de atividades do processo técnico de trabalho desenvolvido por uma equipe multidisciplinar, no qual as especialidades profissionais se complementam e se superam na direção da integralidade da atenção.

Para que a Atenção Socioeducativa possa representar uma mudança radical da Assistência Social, e não apenas meras transformações técnicas localizadas e limitadas, que não podem superar a Atenção Filantrópica, é preciso entendê-la como exigindo um processo social complexo, no qual ocorram simultânea e articuladamente transformações nos planos técnico-científico, político-jurídico, teórico-conceitual e sociocultural, tal como proposto por Amarante (1995) e também por Costa-Rosa (2000; 2011), num plano distinto.

Aqui pode ser bastante útil um esclarecimento sobre a relação dos quatro parâmetros mínimos que Costa-Rosa $(2000,2011)$ propõe como definidores de um determinado paradigma de produção na Saúde Mental: 1) Concepções de objeto e dos meios de ação; 2) Concepções das formas de organização do dispositivo institucional - formas das relações intrainstitucionais; 3) Concepções das formas de relação instituição-território e população-instituição; e 4) Concepções dos efeitos terapêuticos e seus desdobramentos éticos - com as quatro categorias de análise da Reforma Psiquiátrica propostas por Amarante (1995) -, transformações teórico-assistenciais, técnico-assistenciais, jurídico-políticas e culturais. Trata-se de duas modalidades de categorias de análise de estatuto teórico e epistemológico bem diferentes: análise lógico-histórica (estrutural), no primeiro caso, e análise histórica (conjuntural) no segundo.
Com base nesses operadores, procurou-se elaborar uma caracterização de como seriam os paradigmas presentes no campo da Assistência Social na atualidade. Inicialmente, aplicaram-se as quatro categorias de análise histórica e conjuntural de Amarante (1995) para caracterizar o que seria a Atenção Filantrópica e a Atenção Socioeducativa no campo da Assistência Social. Depois, num esforço analítico e dedutivo, utilizaram-se os parâmetros de Costa-Rosa $(2000 ; 2011)$ para configurar de modo mais detalhado o perfil do modo filantrópico e também do modo socioeducativo e demonstrar sua incidência na organização das entidades assistenciais de atenção às crianças e aos adolescentes pobres.

É possível afirmar que a Atenção Filantrópica visaria primordialmente promover uma integração subordinada dos indivíduos pobres no sistema social.

a) No plano científico, o atendimento assistencial é assistencialista e filantrópico, sendo pautado por uma perspectiva disciplinar-correcional que se explicita pelos seguintes binômios: marginalidade - integração social; ociosidade - reeducação profissionalizante; desvio de conduta - reeducação em valores morais; problemas e desajustes psicológicos (cognitivos, carências afetivas e emocionais, agressividade) - tratamento clínico psicoterapêutico individualizado adaptativo e/ou medicalização (ritalina, concerta, anticonvulsivantes, ansiolíticos, calmantes etc.). Predominam as práticas que visam à readaptação, reabilitação e reinserção social, com a intenção de que o indivíduo retorne a uma situação anterior de integração social (na qual provavelmente ele nunca esteve).

b) No plano técnico, a acolhida, as atitudes e o posicionamento dos profissionais técnicos e educadores no atendimento assistencial seriam efetuados por meio da realização de atividades assistenciais, esportivas, recreacionais, culturais e artísticas, tradicionalmente escolares, improvisadas e aleatórias. Tais procedimentos seriam baseados no saber tradicional do mestre (autoritário, corretivo, ortopédico, pedagógico, educativo, terapêutico, preventivo e reabilitador), sendo incorporados pelos diversos trabalhadores, desde os voluntários sem qualificação profissional até os educadores e técnicos em geral: pedagogos, professores de educação física, assistentes sociais, psicólogos etc. O indivíduo é considerado como um objeto de intervenção da equipe institucional. 
c) No plano teórico-conceitual, predomina implicitamente a teoria filantrópica que, fundamentada numa concepção liberal do homem, estigmatiza naturalmente os pobres, entendendo-os como pessoalmente responsáveis por sua condição social, devido, por exemplo, à preguiça e, inclusive, por causa de uma possível degeneração biológica e moral; criminaliza a pobreza, considerando os oprimidos, os explorados e os excluídos do sistema como sendo potencialmente perigosos para a paz e a ordem social, constituindo as classes perigosas. A prática assistencial tradicional, não teorizada nem problematizada pelos profissionais, baseia-se em teorias filosóficas inatistas e empiristas; a Psicologia é tradicional, eminentemente clínica e fortemente patologizante do indivíduo; a Pedagogia oscila entre uma tendência tradicional e autoritária (sem preocupar-se com a transmissão de conteúdos) e uma tendência renovada (psicologizante e espontaneísta); a Sociologia revela-se de matiz funcionalista e reacionária.

d) No plano político-jurídico: a autoridade é considerada a figura legítima e incontestavelmente detentora do poder político, econômico e social que distribui benesses, favores e auxílios aos desfavorecidos, carentes e necessitados. Mesmo que a lei (Brasil, 1988) reconheça os direitos de cidadania e procure regulamentá-los, ela é estrategicamente reduzida a uma mera formalidade vazia e, assim, neutralizada. Os pobres são tratados com paternalismo, por meio de práticas assistencialistas, benemerentes e samaritanas, focalizadas, mínimas, sem planejamento sistêmico e descontínuas.

e) No plano sociocultural, os pobres também são estigmatizados e culpabilizados pessoalmente por sua situação. Isso pode ser sintetizado pela afirmação lapidar de Patto (1990, p.209): "... o protótipo das representações sociais do pobre na cultura brasileira inclui as seguintes características: sexualmente promíscuo, primitivo, anômico, vadio, pouco inteligente, violento e com vocação para a marginalidade e delinquência". Os pobres e os miseráveis são percebidos como um peso que onera os cofres públicos de modo indevido.

O modelo dialética e diametralmente oposto seria constituído pelo que poderia ser denominado de Atenção Socioeducativa, cujo objetivo maior seria a viabilização de direitos para famílias e indivíduos, considerados como cidadãos e como sujeitos. Sujeito é o

292 homem enquanto ator social e indivíduo agente, pessoa autônoma e cidadão - na ordem da política, é ainda o ego cognoscente -, o "eu" centrado na consciência racional e reflexiva, no plano da epistemologia tradicional. Mas, fundamentalmente, inclui as noções lacanianas de "sujeito do inconsciente", de "sujeito dividido" e de "sujeito de desejo" (Cabas, 2009; Fink, 1998; Olgivie, 1988), segundo as quais, "... o ego ou o eu não cobre a totalidade do sujeito"(Vallejo \& Magalhães, 1979, p.158).

a) No plano científico, o atendimento socioeducativo é baseado na concepção do sujeito como cidadão de direitos, traduzida pelos conceitos de defesa, de proteção integral, de controle social popular, de promoção e de transformação social. O sujeito é entendido como sendo produtor e, ao mesmo tempo, uma produção coletiva e dialética do contexto social, e suas demandas e necessidades precisam ser acolhidas a partir de uma compreensão sócio-histórica. A análise crítica da produção coletiva da vida social torna compreensíveis as características do sujeito e seus problemas, superando hipóteses inatistas, ambientalistas e adotando uma compreensão dialética crítica e histórica da vida social. Supera-se a naturalização da pobreza na busca de suas causalidades sociais estruturais.

b) No plano técnico, as atitudes dos diversos profissionais incluem a acolhida, a escuta, a visita, o encaminhamento, o acompanhamento, o monitoramento e a avaliação do processo de atendimento. $\mathrm{O}$ atendimento também pode incluir a oferta de projetos, de programas e de serviços socioeducativos, conforme as características do estabelecimento assistencial, oferecendo atividades educativas, esportivas, recreacionais, culturais e artísticas, pautadas pelo ideário da Pedagogia Dialética e pela Educação Popular (Pontual \& Ireland, 2006). No processo participativo e democrático institucional e social, todos são sujeitos: usuários, educadores, técnicos etc. Os trabalhadores da Assistência Social são sujeitos viabilizadores e mediadores de direitos para outros sujeitos, promovendo um processo de politização do atendimento, orientando os usuários para as questões relacionadas com direitos de cidadania, democracia, democratização e participação popular.

c) No plano teórico-conceitual, a prática socioeducativa baseia-se em múltiplas perspectivas: na Psicanálise do campo de Freud e Lacan, instrumentalizando-se com os conceitos de sujeito do inconsciente, de transferência e ética, procurando superar uma forte 
tradição na Psicologia quanto a formulações essencialistas da subjetividade (Lacan, 1998). Ela tende a conceber o homem como um sujeito dotado de uma interioridade psicológica, de um psiquismo que habitaria a interioridade do seu corpo, utilizando alguns conceitos que explicitariam esse objeto psicológico pretensamente natural, substancial e a-histórico, tais como: consciência racional, identidade ou personalidade una e indivisa, conduta, comportamento, psiquismo etc. Já a Psicanálise do campo de Freud e Lacan (Elia, 2004; Garcia-Rosa, 2009) postula que o homem vivencia um complexo processo de subjetivação ou de constituição da subjetividade, processo que estrutura a subjetividade ou a realidade psíquica sob a forma de modalidades diversas (recalcamento, foraclusão, renegação), propensas a impasses variados (Lacan, 1979; 1998). Essa perspectiva é importante, pois, entre muitas outras questões relevantes, permite a superação de inúmeras dicotomias que pululam no campo psi: interno/externo; psíquico/orgânico; comportamento/vivências subjetivas; natural/social; autonomia/determinação; doença-cura etc. Também se baseia nas vertentes filosóficas e sociológicas do materialismo histórico dialético (Marx), da genealogia (Foucault) e da filosofia da diferença (Deleuze). A Pedagogia fundamenta-se numa concepção dialética e crítica (Educação Popular). A Sociologia é crítica e dialética, alinhada com os interesses do polo subordinado, visando à emancipação popular e à transformação social. O Serviço Social alinha-se com uma perspectiva crítico-dialética (materialismo histórico), buscando avançar na implementação do Sistema Único de Assistência Social e da política pública de atendimento à criança e ao adolescente. O nível de formação dos trabalhadores é complexo e exigente, visando lidar de modo complexo e transdisciplinar com questões igualmente complexas.

d) No plano político-jurídico, parte-se daquilo que a lei estabelece, institui, fundamenta e regulamenta quanto aos direitos de cidadania, à criação de mecanismos democráticos de participação social e de controle social sobre o poder político (Sistema Único de Saúde (SUS), ECA, LOAS, SUAS). O objetivo é implementar efetivamente a lei e promover a conquista de novos direitos, ampliando a cidadania na direção de uma democracia popular.

e) No plano sociocultural, faz-se circular discursos que deem visibilidade às práticas dialeticamente alternativas à Atenção Filantrópica: escuta psicanalítica das demandas inconscientes, formação da consciência crítica e política, processos de organização popular, movimentos de reivindicação, processos institucionais que se pautem pela cidadania dos sujeitos de direitos, trabalhando coletivamente para a materialização efetiva de tais direitos. É fundamental desconstruir os discursos hegemônicos que associam, sem mais, a pobreza com a criminalidade, e todo o imaginário autoritário, intolerante e repressivo típico do reacionarismo político ainda vigente.

\section{O modo filantrópico}

Ao indagar pelas condições de existência das entidades assistenciais para crianças e adolescentes, procurou-se estudar a conjuntura sócio-histórica mais ampla nas quais elas emergem. Assim, detectou-se a existência de dois paradigmas contraditórios, no sentido dialético, no campo da Assistência Social: um denominado modo filantrópico e outro que estaria emergindo, ainda de modo lento, chamado modo socioeducativo. A seguir, será apresentada a incidência de ambos na forma de funcionamento e no sentido da produção social de entidades assistenciais que atendem a crianças e adolescentes vítimas de processos sociais causadores de pobreza, procurando produzir sua caracterização paradigmática.

Com base nos dados levantados sobre as entidades assistenciais que atendem a crianças e adolescentes, elaborou-se uma síntese a partir do esquema lógico-histórico e estrutural proposto por Costa-Rosa (2000) para a realização de um trabalho de análise institucional. Procurou-se problematizar o funcionamento dos estabelecimentos assistenciais que atendem a crianças e a adolescentes, focalizando as relações de poder, de saber e de produção de subjetividade que os organizam na atualidade. Pode-se afirmar que o modo filantrópico é hegemônico e predominante nos diversos estabelecimentos assistenciais atuais.

O modo filantrópico como organizador das práticas, dos saberes e dos poderes no campo da Assistência Social corresponde a uma entidade assistencial que se organiza a partir de uma lógica menorista, ainda articulada por um discurso filantrópico autoritário e crimi- 
nalizante das classes populares, baseada na noção jurídica - já superada legalmente pelo Estatuto dos Direitos da Criança e do Adolescente (Brasil, 1990) -, da "situação irregular" e desenvolvendo práticas preventivas repressivas, correcionais, moralizadoras e essencialmente adaptativas.

1) Quanto à concepção do objeto institucional, crianças e adolescentes são tomados como objeto de atividades assistenciais, pedagógicas e psicológicas, com exclusão da sua subjetividade (que, quando emerge, costuma ser tomada como problemática e dificultadora do trabalho assistencial), visando à normalização das condutas individuais, por meio de práticas ortopédicas. O usuário é considerado um aluno ou um educando, um carente assistido - quando não um delinquente ou marginal, e deve manifestar condutas previamente esperadas e adequadas: docilidade, obediência, cooperação, capacidade de aprendizagem e de desenvolvimento positivo de suas qualidades e potencialidades pessoais, tornando exitoso o trabalho social realizado com ele.

Seu objeto institucional seria a educação social da clientela: a cidadania obedeceria a um modelo universal a ser inculcado e introjetado (trata-se de um objeto com estatuto ontológico, constituído pelo modelo pequeno burguês de existência: o indivíduo livre, talentoso, trabalhador, consumidor, membro da sociedade das pessoas de bem, como propõe o discurso filantrópico enunciado por atores institucionais que atuam em entidades assistenciais). As práticas e técnicas sociais, pedagógicas e psicológicas formativas implementam procedimentos microfísicos disciplinares: observação do comportamento em meio aberto, controle, vigilância, exame, correção, ortopedia, normalização.

2) Predomina uma centralização autoritária e vertical na organização das relações intrainstitucionais (poder público municipal, judiciário, conselhos municipais, estabelecimentos assistenciais, diretores e educadores das entidades). O fluxo do poder decisório está concentrado na hierarquia piramidal e na heterogestão. O organograma formal e informal é verticalizado, os cargos baseiam-se na capacitação profissional dos atores institucionais e no privilégio. Predomina uma divisão taylorizada do trabalho: os técnicos pensam, 294 decidem, mandam e os educadores dos estabeleci- mentos são executores tarefeiros. A organização arquitetônica e do mobiliário manifesta-se na centralidade dos estabelecimentos de assistência e nos privilégios dos dirigentes, em detrimento da precariedade das condições dos educadores e da clientela. O trabalho educativo também obedece a uma divisão taylorizada; dirigentes, educadores e demais funcionários ocupam-se, de modo segmentado, da clientela: esportes, artes circenses, lazer, atividades escolares, informática, alimentação, higiene, atendimento clínico psicoterapêutico individual e grupal etc.

A organização das relações intrainstitucionais está centralizada no diretor e na equipe de educadores: há poucos canais de participação no estabelecimento e os que existem acabam se tornando instrumentos formais, destituídos de eficácia deliberativa e autogestiva. A roda de conversa - instrumento pretensamente democrático e participativo utilizado com os usuários no início das atividades diárias -, também não funciona como instância de espaço dialógico verdadeiro para a equipe de educadores e para a direção do estabelecimento.

O fluxo do poder decisório e de execução é hierárquico, escalonado, heterogestivo. O organograma formal e informal tende a ser verticalizado: os educadores sociais não chegam a constituir equipes de trabalho multidisciplinar, tendendo a trabalhar de modo isolado, numa estratégia de cumprimento burocrático das tarefas, imperando a lei do menor esforço. A equipe de gestão técnica trabalha de modo isolado, sem maior interação com os demais grupos da entidade. A equipe de educadores sociais desempenha um papel de vigilância e de controle da conduta das crianças e dos adolescentes, no processo assistencial institucional. Predomina, na cultura institucional, o desperdício e uma certa irresponsabilidade no uso dos bens - a estratégia da "mamata" por parte dos funcionários, com o objetivo de obter vantagens pessoais indevidas e a improvisação no trabalho, fazendo de conta que se trabalha e demonstrando estar ocupado.

Com relação a isso, seria necessário educar a equipe de profissionais para a responsabilidade e a economia, para o compromisso ético e para o planejamento participativo (incluindo a questão do financiamento, da execução, do monitoramento e da avaliação). Sobre dinheiro, custos e salários, não se fala 
abertamente na entidade, reproduzindo as relações patronais tradicionais da sociedade capitalista. Também seria preciso criar e desenvolver motivos, interesses e necessidades humanizadoras e humanizantes, tanto nos usuários quanto nos educadores: o gosto pelo conhecimento, o valor da expressão artística, a importância da reflexão filosófica, do posicionamento ético congruente e, também, da militância política crítica.

3) Quanto à relação da instituição assistencial com a clientela, no plano geográfico, predomina o atendimento da encomenda social e a entidade apresenta-se como espaço depositário e de confinamento, arregimenta crianças e adolescentes e procura desenvolver com eles atividades assistenciais, sendo percebida como espaço de proteção, que proporciona a guarda, a tutela e a ocupação do tempo dos usuários, mantendo-os longe das ruas, da mendicância, da criminalidade e da violência, de modo preventivo. O espaço geográfico aberto e amplo é visto como potencialmente perigoso e prenhe de situações de risco para crianças e adolescentes; por isso, o processo de atendimento assistencial é desenvolvido num estabelecimento de contenção que funciona com base na vigilância, no controle do comportamento e na persuasão - pretensamente não ostensivos ou violentos -, próprios da pedagogia, da Psicologia e do Serviço Social.

Há uma forte tendência em reproduzir a dinâmica problemática da instituição escolar, com clausura e fechamento, com atividades de reforço escolar, lista de chamada e monitoração das presenças, livro de ocorrências para registrar o mau comportamento dos usuários, aplicação de castigo às crianças (mantendo-as sentadas num lugar durante longo tempo, privando-as da refeição, de passeios etc.), recebimento de broncas dos educadores e, inclusive, a possibilidade de expulsão do estabelecimento devido a problemas de comportamento. Não há critérios claros para os procedimentos pedagógicos desenvolvidos pelos educadores, que tendem a trabalhar a partir do senso comum. Os educadores desempenham mais o papel de professores tradicionais do que de educadores sociais. Normalmente, eles não fizeram uma opção ética para trabalhar em um estabelecimento assistencial que atende a uma clientela pobre e não costumam estar alinhados com os interesses dos grupos populares, apenas realizam um trabalho profissional que visa à sua sobrevivência pessoal e familiar.
A escolarização das políticas públicas voltadas para crianças e adolescentes aumenta na mesma proporção em que os educadores sociais são recrutados entre os professores da rede municipal de educação escolar - que são cedidos pelo poder público como benesse e favor pessoal -, trazendo para os estabelecimentos assistenciais os hábitos, os vícios e os problemáticos esquemas de funcionamento da instituição escolar (Patto, 1990). A formação técnica e profissional das equipes dirigentes e dos educadores deixa muito a desejar, com relação à opção política pelas classes populares e quanto a estratégias de educação social que se pautem pelo trabalho de escuta, de conscientização, de organização com vistas à mobilização e à emancipação popular. O principal mecanismo e operador microfísico da entidade baseia-se na vigilância em meio aberto, na suplência da família e da escola no processo de normalização social de crianças e de adolescentes. No estabelecimento assistencial já se prefiguram as eventuais possibilidades delinquentes e antissociais da clientela pobre. Os complementos assistenciais de ordem pedagógica e psicológica acabam funcionando como uma cobertura que se sobrepõe a uma tecnologia disciplinar-correcional, produzindo, desse modo, efeitos pouco consistentes no cotidiano institucional, quanto aos sujeitos cidadãos de direitos, que são as crianças e adolescentes.

No plano do imaginário coletivo, a entidade aparece como provedora, como local que oferece proteção, alimentação, educação e oportunidades positivas para crianças e para adolescentes, pois desenvolve práticas filantrópicas e assistencialistas buscando uma certa promoção social por meio da escolarização e de tentativas precárias de profissionalização dos adolescentes, visando à sua inserção no mercado de trabalho. Espera-se que o estabelecimento possa educar as crianças, ajudando-as a ter sucesso na escola e preparando-as para o futuro profissional. Além disso, a participação em estabelecimentos assistenciais é também porta de acesso para a obtenção de auxílio familiar, por meio de ajudas municipais (cestas básicas) ou estaduais e federais (bolsas variadas), estando incluída como uma das condicionalidades desses auxílios.

No plano simbólico, verifica-se no estabelecimento assistencial a contradição entre um discurso que proclama a"proteção integral e a defesa dos direitos 
fundamentais da criança e do adolescente" (Brasil, 2007b) e uma tutela em meio aberto, informal, incompleta, precária, filantrópica, caritativa, com práticas amadoras, benemerentes, assistencialistas, repressivas e correcionais. O discurso é liberal, os direitos constitucionais da criança e do adolescente como cidadãos são reduzidos a valores formais, abstratos e observa-se que as práticas são inevitavelmente autoritárias nesses estabelecimentos. Os instrumentos (práticas, saberes e discursos) utilizados pela entidade estão em dissonância, quando não em franca contradição com seus objetivos oficiais, e não podem produzir aquilo a que se propõem. As próprias crianças sentem vergonha de frequentar as entidades, pois isso as sobrecodifica com um estigma social: são identificadas pela população como sendo crianças pobres, carentes e assistidas pelas entidades assistenciais. Elas não se percebem nem são percebidas como cidadãos sujeitos que têm direito à educação, ao lazer, à atenção assistencial de qualidade, cuja oferta é de responsabilidade do Estado.

4) Quanto aos efeitos típicos da instituição assistencial em termos de performance ética, ela acaba produzindo um certo tipo de mais-valia, fazendo o capital girar no terceiro setor (Montaño, 2007), pois a gestão e a administração da pobreza gera lucros, empregos, investimentos e dividendos empresariais e também políticos para o governo municipal; muitas vezes reproduz as relações sociais de dominação-subordinação-exclusão, numa imitação muito precária da escola e, finalmente, tende a produzir uma subjetividade normalizada, serializada, submetida, dócil, politicamente inócua e útil, predominando a adaptação social.

\section{Caracterização do modo socioeducativo}

A partir do referencial lógico-estrutural de Costa-Rosa (2011) para a análise institucional, pode-se delinear um paradigma diametralmente oposto ao modo filantrópico mapeado no campo da Assistência Social no qual se encontram os estabelecimentos assistenciais que atendem a crianças e a adolescentes empobrecidos, oprimidos e excluídos. O desenho do Modo socioeducativo é uma dedução lógica que o instrumental analítico permite esboçar, sendo que ainda são raros os indícios que dele se podem encontrar no campo social 296 concreto.
No campo da Assistência Social, o modo socioeducativo seria dotado com as seguintes características:

1) Quanto à concepção do processo social que identifica de modo intrínseco a pobreza-delinquência e dos meios teórico-técnicos empreendidos para lidar com esse processo, propõe-se para a Atenção Socioeducativa: determinação e consistência sociocultural e psíquica dos problemas, e não orgânica ou psicológica/subjetiva individual; os conflitos e as contradições devem ser considerados tanto como constitutivos do sujeito, quanto contingentes à sua situação e, portanto, não são necessariamente removidos como efeito das ações socioeducativas; tratamento da demanda e não dos problemas e das dificuldades emergentes; oferta de atenção psicossocial, de escuta e de uma clínica da construção de si, e não clínica da observação e da reabilitação (integração social), tomada do indivíduo como sujeito de projeto, como propõe Heidegger (1995), o homem como infinito projetar-se, infinito cuidar-se; e do inconsciente, como se propõe na psicanálise, e não tomada do sujeito como objeto de tutela ou de intervenção. A desinstitucionalização do paradigma pobreza-delinquência e sua substituição pelos conceitos de cidadania e de "sujeito cidadão de direitos" (Brasil, 1988; 1990; 2007b), conjuntamente com a configuração interdisciplinar e da atitude transdisciplinar do conjunto dos trabalhadores e de suas ações, são pré-requisitos necessários para a implicação subjetiva dos usuários e da população.

Exigências: desinstitucionalização e não institucionalização da questão pobreza-delinquência-criminalidade; despatologização e não patologização do indivíduo (abolindo a clínica individual terapeutizante e/ou medicalizada como resposta única ou preponderante e a priori); implicação subjetiva e sociocultural e não reificação ou objetificação; "sujeito cidadão de direitos" e não pobreza-cidadania que promove apenas uma inclusão social subordinada; clínica ampliada interdisciplinar e transdisciplinar (Educação Popular; Psicanálise, Materialismo Histórico, Filosofia da Diferença) e não clínica psicológica/psiquiátrica ou das especialidades.

2) Quanto à concepção da organização e das relações intrainstitucionais, inclusive da divisão do trabalho interprofissional, são exigências da Atenção 
Socioeducativa, principalmente: horizontalização das relações intrainstitucionais, e não verticalização (sabe-se que qualquer relação da instituição como dispositivo e de seus agentes com a clientela e com a população depende da relação dos agentes institucionais entre si); distinção entre poder decisório (de origem política) e de coordenação (com possível origem no plano do saber), e não amálgama saber/poder; livre trânsito do usuário e da população em forma de autogestão e cogestão, e não heterogestão; divisão do trabalho interprofissional integrada em profundidade (superação da divisão do trabalho típica do modo capitalista de produção) e não divisão do trabalho interprofissional segundo o modelo taylorista. No limite das possibilidades do Modo socioeducativo, deve-se pautar por uma postura que pode ser mais bem designada pelos conceitos de interdisciplinaridade e de transdisciplinaridade.

Exigências: horizontalização e não verticalização das relações intrainstitucionais; participação e não exclusão segregadora; autogestão e cogestão e não gestão por delegação; interprofissionalidade integradora do processo de produção do produto e não interprofissionalidade fragmentadora segundo a lógica do modo capitalista de produção; transdisciplinaridade como horizonte mais amplo: superação dos especialismos e do esquema sujeito-objeto.

3) Quanto à concepção das relações da instituição e de seus agentes com a clientela e com a população em geral, são exigências essenciais da Atenção Socioeducativa: o estabelecimento institucional deve se situar como exterioridade em relação ao território (porosidade), garantindo nele o livre trânsito de todos, visto que o estabelecimento não é espaço depositário e aprisionante dos usuários e, eventualmente, da população, como no Modo filantrópico; as relações devem ser de interlocução, de diálogo entre sujeitos e não do tipo autoridade-subordinado; as ações visam à integralidade em extensão (no território) e em profundidade (considerando toda a complexidade das demandas), e não ações de atenção estratificada por níveis (proteção básica, proteção especial de média e de alta complexidade). Instituições típicas: associações de moradores, entidades assistenciais abertas, cooperativas populares, CRAS, CREAS, todas pautadas pelo ideário da Educação Popular e não pelo da filantropia. Desinstitucionalizar as políticas e as práticas de Assistência Social, na lógica do Modo socioeducativo, significa superar a organização de serviços baseados nos níveis de proteção, propiciando a unicidade de responsabilidade sobre o território; superar o fechamento institucional em favor da consideração das sociedades locais com seus conflitos e contradições reais; superar o monopólio das especialidades profissionais, utilizando as múltiplas potencialidades dos trabalhadores institucionais para a ativação de todos os recursos disponíveis, inclusive os dos usuários das instituições.

Exigências: interlocução, diálogo horizontal entre sujeitos; livre trânsito e não interdição e clausura ou espaço depositário; atenção integral e territorializada e não estratificada por níveis. Desinstitucionalização do Modo filantrópico e sua substituição pelo Modo socioeducativo.

4) Quanto à concepção efetivada dos efeitos éticos e de suas ações em termos políticos, educativos e terapêuticos, propõe-se como ética da Atenção Socioeducativa: por um lado, reposicionamento do sujeito (ética da singularização) e, por outro, destituição subjetiva (com superação do imaginário) e não integração social (adaptação social ortopédica). Este reposicionamento pode ser pensado tendo como horizonte a recuperação-construção-reivindicação dos direitos de cidadania, passando pela conquista do poder de contratualidade social, até a implicação subjetiva (entendida como a capacidade do sujeito de situar-se de modo ativo frente aos conflitos e contradições que atravessa e pelos quais é atravessado). A implicação subjetiva, como forma de singularização, supõe, ainda, a apropriação do desejo com seus vetores inconscientes e de devir; e a possibilidade de abrir-se para uma dimensão do saber que transcende o enciclopédico e o de mestria, para objetos que não se esgotam nos objetos imediatos, de "valência imaginária"(Valas, 2001, p.69).

Exigências: relação sujeito-desejo e carecimento-ideais (Costa-Rosa et al., 2003; Marx, 1978) e não ego-realidade ou carência-suprimento; implicação subjetiva e sociocultural (singularização) e não integração social (adaptação social ortopédica).

Ao Modo socioeducativo no campo da Assistência Social corresponderia uma entidade assistencial na qual a Atenção Socioeducativa estaria organizada a partir da lógica dos direitos de cidadania, que se articularia 
num discurso crítico, dialético e politizado, baseando-se na noção jurídica de proteção integral e desenvolvendo práticas institucionais educativas populares e emancipadoras. Constata-se que algo dessa ordem é ausente ou, quando muito, absolutamente incipiente na realidade das entidades assistenciais pesquisadas.

\section{Considerações Finais}

Certamente pode ser mais fácil entender os problemas que a teoria e a perspectiva de análise apresentam e discutem do que explicitar quais são as propostas para o equacionamento das questões em pauta. Se não é fácil propor soluções para problemas complexos - e soluções simples não existirão, já que os problemas são complexos -, explicitar problemas mal colocados e opor a eles a precisão de um problema talvez já seja uma contribuição importante, embora modesta, procurando evitar qualquer atitude onipotente.

Ainda com base na grade analítica histórico-conjuntural utilizada, é possível perceber que há um imenso trabalho crítico e inovador a ser realizado nos diversos campos: teórico-assistencial, técnico-assistencial, jurídico-político e sociocultural, na esfera da Assistência Social, para potencializar a emergência do que pode ser denominado como modo socioeducativo, ainda em construção.

No campo teórico-assistencial é preciso desconstruir conceitos e práticas sustentadas pela perspectiva filantrópica autoritária e reacionária que ainda predomina na Assistência Social, no Serviço Social conservador e alienado, na Psicologia patologizante, psicologizante e culpabilizante do indivíduo e da família, na Pedagogia tradicional e elitista e na Sociologia funcionalista acerca da questão social em geral e da pobreza em particular. A pobreza é uma questão fundamentalmente política e é preciso situá-la nesse campo concreto, de lutas e embates sociais pela construção de uma sociedade mais justa. É preciso construir noções de direitos humanos, de cidadania, de democracia popular, de Atenção Socioeducativa, de atenção psicossocial, de educação popular e de pensamento crítico e dialético, fazendo frente ao paradigma filan298 trópico hegemônico.
No campo técnico-assistencial é preciso criatividade para inventar e ousar criar outras estratégias educacionais, pedagógicas, psicológicas e assistenciais, aprimorando a formação das equipes de profissionais. É fundamental superar o atendimento aos pobres e partir da Atenção e do atendimento ao cidadão de direitos, rompendo com práticas disciplinares-correcionais e aumentando a possibilidade de que o indivíduo se construa a partir do status de sujeito de direitos, sendo capaz de autonomia crescente e de maior contratualidade social. Mais do que capacidade técnica, é fundamental a adoção de um posicionamento ético, profissional e político, alinhado com os interesses das classes populares.

No âmbito jurídico-político, é possível constatar transformações fundamentais que vêm ocorrendo no ordenamento jurídico nas últimas décadas, começando pela Constituição Federal (Brasil, 1988), passando pelo ECA (Brasil, 1990), pela LOAS (Brasil, 1993; 2011), pela PNAS (Brasil, 2004), pelo SUAS (Brasil, 2005). Há muito de lutas populares por trás dessas construções legais e também há muitas concessões estratégicas por parte do poder político da elite que domina o Estado. Todo esse arcabouço jurídico contém aspectos louváveis e pontos bastante problemáticos. Contudo, diante das lideranças políticas, no âmbito municipal, que ainda são extremamente patrimonialistas, autoritárias, concentradoras de poder, corporativistas e clientelistas, orientadas por um ideário filantrópico profundamente elitista e reacionário, elas até podem ser consideradas leis arrojadas, apesar de suas diversas limitações. Por exemplo, as prefeituras municipais instalam todos os conselhos municipais que a lei ordena: Conselho Municipal dos Direitos da Criança e do Adolescente, Conselho Tutelar, Conselho Municipal de Assistência Social, Conselho Municipal de Educação, do Idoso, do Deficiente etc., mas não admite partilhar o planejamento, a deliberação política, a destinação orçamentária, a execução técnica e a avaliação com os conselhos municipais, que normalmente são reduzidos a instâncias burocráticas que simplesmente sancionam tudo o que o executivo determina, de modo cartorário e subordinado. De acordo com a experiência de imersão realizada no campo da Assistência Social, verificou-se que ainda não há quadros de profissionais no poder público nem na sociedade civil que estejam à altura do nível democrático e participativo que a legislação propõe. É preciso lutar para 
conseguir exercer e implementar efetivamente as prerrogativas legais estabelecidas, buscando sempre aperfeiçoar a legislação vigente, em um direcionamento constante para a criação e o afiançamento de novos direitos.

No plano sociocultural, deparou-se com a persistência da perspectiva enviesada da filantropia reacionária, presente na mentalidade de gestores municipais, de técnicos, de conselheiros, tanto do poder público quanto da sociedade civil, de pais, de educadores sociais, de dirigentes de entidades, assim como em planos de trabalho, em atitudes, em práticas, em discursos. É surpreendente a pregnância do paradigma filantrópico, aliado com o clientelismo assistencialista do poder público e com sua resistência às inovações jurídicas e institucionais promovidas pelo Estado, no âmbito das políticas públicas para a Assistência Social e para a criança e o adolescente no País. Afirmar que a Assistência Social é uma política pública de dever do Estado e de direito do cidadão e que crianças e adolescentes são sujeitos de direitos ainda é muito mais um projeto a ser construído do que uma realidade constatada.

\section{Referências}

Alberto, M. F. P. (2008). O papel do psicólogo e das entidades junto a crianças e adolescentes em situação de risco. Psicologia, Ciência e Profissão, 28(3), 558-573.

Amarante, P. (1995). Loucos pela vida: trajetória da reforma psiquiátrica no Brasil. Rio de Janeiro: Fiocruz.

Assis, S. G. (Org.). (2009). Teoria e prática dos conselhos tutelares e conselhos dos direitos da criança e do adolescente. Rio de Janeiro: Fiocruz.

Baremblitt, G. F. (1998). Compêndio de análise institucional e outras correntes: teoria e prática. Rio de Janeiro: Record.

Barreto, A. F. (2011). Sobre a dor e a delícia da atuação do psicólogo no SUAS. Psicologia, Ciência e Profissão, 31(2), 406-419.

Barus-Michel, J. (2004). O sujeito social. Belo Horizonte: Puc Minas.

Benelli, S. J. (2004). A instituição total como agência de produção de subjetividade na sociedade disciplinar. Estudos de Psicologia (Campinas), 21(3), 237-252. doi: 10.1590/50 103-166X2004000300008.

Benelli, S. J. (2009). A cultura psicológica no mercado de bens de saúde mental contemporâneo. Estudos de Psicologia (Campinas), 26(4), 515-536. doi: 10.1590/50103-16 6X2009000400012.

Benelli, S. J. (2010). Cartografia das instituições de Assistência Social a crianças e adolescentes num município do interior do Estado de São Paulo (Tese de pós-doutorado não- publicada). Programa de Pós-Doutorado em Psicologia e Sociedade, Universidade Estadual Paulista.

Benelli, S. J., \& Costa-Rosa, A. (2010). A construção de redes sociais: entre a conexão e a captura na gestão dos riscos sociais. In E. P. Constantino (Org.), Psicologia, estado e políticas públicas (pp.25-85). Assis: Unesp.

Bock, A. M. B. (2004). A perspectiva sócio-histórica de Leontiev e a crítica à naturalização da formação do ser humano: a adolescência em questão. Cadernos Cedes, 24(62), 26-43.

Bock, A. M. B. (2007). A adolescência como construção social: estudo sobre livros destinados a pais e educadores. RevistaSemestral daAssociação Brasileira de Psicologia Escolar e Educacional, 2(1), 63-76.

Bock, A. M. B. (Org.). (2009). Psicologia e compromisso social. São Paulo: Cortez.

Botarelli, A. (2008). Opsicólogo nas políticas de proteção social: uma análise dos sentidos e das práxis (Tese de doutorado não-publicada). Programa de Pós-Graduação em Psicologia Social, Pontifícia Universidade Católica de São Paulo.

Brasil. Presidência da República. (1988). Constituição da República Federativa do Brasil. Brasília: Presidência da República Casa Civil. Recuperado em março 10, 2008, disponível em <http://www.planalto. gov.br/ccivil_03/ Constituicao/constitui\%C3\%A7ao_ compilado. htm>.

Brasil. Presidência da República. (1990, julho 16). Lei nº 8.069 , de 13 de julho de 1990. Dispõe sobre o estatuto da criança e do adolescente e dá outras providências. Diário Oficial da União, Seção 1. Recuperado em março 10, 2008, disponível em < http://www.planalto. gov.br/ccivil/ Leis/L8069.htm>.

Brasil. Presidência da República. (1993; dezembro 12). Lei no 8.742, de 7 de dezembro de 1990. Dispõe sobre a organização da assistência social e dá outras providências. Diário Oficial da União, Seção 1. Recuperado em março 10, 2008, disponível em <http://www.mds. gov.br/cnas/ legislacao/leis>.

Brasil. Ministério do Desenvolvimento Social. (2004). Política nacional de assistência social enorma operacional básica de serviço social. Brasília: MDS. Recuperado em março 10, 2008, disponível em <http://www.mds.gov.br/cnas/ legislacao/leis>.

Brasil. Ministério do Desenvolvimento Social. (2005). Norma operacional básica do sistema único de assistência social. Brasília: MDS. Recuperado em março 10, 2008, disponível em <http://www.mds.gov.br/cnas/politica-e-nobs>.

Brasil. Ministério do Desenvolvimento Social. (2006a). Orientações técnicas para o centro de referência da assistência social - CRAS. Brasília: MDS. Recuperado em março 10, 2008, disponível em <http://www.mds.gov.br/cnas/ politica-e-nobs>.

Brasil. Ministério do Desenvolvimento Social. (2006b). Orientações técnicas para o Programa Bolsa Família - PBF. Brasília: MDS. Recuperado em março 10, 2008, disponível em <http://www.mds.gov.br/cnas/politica-e-nobs>.

Brasil. Ministério do Desenvolvimento Social. (2006c). Orientações técnicas para o centro de referência especializado 
em assistência social. Brasília: MDS. Recuperado em março 10, 2008, disponível em <http://www.mds.gov.br/cnas/ politica-e-nobs>.

Brasil. (2007a). Conselho Municipal dos Direitos da Criançae do Adolescente e Conselho Tutelar: orientações para criação e funcionamento. Brasília: Conanda.

Brasil. (2007b). Parâmetros para criação e funcionamento dos Conselhos dos Direitos da Criança e do Adolescente. Brasília: SEDH.

Brasil. Ministério do Desenvolvimento Social. (2009a). Tipificação nacional de serviços socioassistenciais. Brasília: MDS. Recuperado em dezembro 12, 2009, disponível em <http://www.mds.gov.br/cnas/politica-e-nobs>.

Brasil Ministério do Desenvolvimento Social. (2009b). Orientações técnicas para o Centro de Referência da Assistência Social - CRAS. Brasília: MDS. Recuperado em dezembro 12, 2009, disponível em <http://www.mds. gov.br/cnas/politica-e-nobs>.

Brasil. Ministério do Desenvolvimento Social. (2011, julho 7). Lei $n^{\circ} 12.435$, de 3 de julho de 2011. Altera a Lei $n^{\circ}$ 8.742, de 7 de dezembro de 1993, que dispõe sobre a organização da assistência social. Diário Oficial da União, Seção 1. Recuperado em julho 30, 2011, disponível em <http://www.mds.gov.br/cnas/legislacao/leis>.

Cabas, A. G. (2009). O sujeito na psicanálise de Freud a Lacan: da questão do sujeito ao sujeito em questão. Rio de Janeiro: Jorge Zahar.

Centro de Referência Técnica em Psicologia e Políticas Públicas. (2007). Referência técnica para atuação do(a) psicólogo(a) no CRAS/SUAS. Brasília: CFP.

Centro de Referência Técnica em Psicologia e Políticas Públicas. (2009). Serviço de proteção social a crianças e adolescentes vítimas de violência, abuso e exploração sexual e suas famílias: referências para a atuação do psicólogo. Brasília: CFP.

Conselho Federal de Psicologia. (2010). Política de assistência social. Diálogos, 7(7), 3-56.

Conselho Federal de Psicologia. (2011). VI Seminário Nacional de Psicologia e Políticas Públicas: democracia e promoção de Direitos. Salvador: CFP.

Conselho Federal de Serviço Social. (2007). Parâmetro para atuação de assistentes sociais e psicólogos (as) na Política de Assistência Social. Brasília: CFP.

Conselho Regional de Psicologia da 6a Região. (Org.) (2007). A psicologia promovendo o ECA: reflexões sobre o sistema de garantia de direitos da criança e do adolescente. São Paulo: CRP.

Constantino, E. P. (Org.). (2010). Psicologia, estado e políticas públicas. Assis: Unesp.

Costa-Rosa, A. (2000). O modo psicossocial: um paradigma das práticas substitutivas ao modo asilar. In P. D. C. Amarante (Org.), Ensaios de loucura e civilização (pp.141-168). Rio de Janeiro: Fiocruz.

Costa-Rosa, A. (2011). Operadores fundamentais da atenção psicossocial: contribuição a uma clínica crítica dos processos de subjetivação na saúde coletiva (Tese de livre-docência não-publicada). Programa de Livre-Docência em Psicologia Clínica, Universidade Estadual Paulista.

Costa-Rosa, A., Luzio, C. A., \& Yasui, S. (2003). Atenção psicossocial: rumo a um novo paradigma em saúde mental coletiva. In P. Amarante (Org.), Archivos de saúde mentale atenção psicossocial (pp.13-44). Rio de Janeiro: Nau.

Cruz, L. R., \& Guareschi, N. (2004). Sobre a psicologia no contexto da infância: da psicopatologização à inserção política. Revista Aletheia, 20(2), 77-90.

Cruz, L. R., \& Guareschi, N. (Orgs.). (2009). Políticas públicas e assistência social: diálogo com as práticas psicológicas. Petrópolis: Vozes.

Cruz, L., Hillesheim, B., \& Guareschi, N. (2005). Infância e políticas públicas: um olhar sobre as práticas psi. Psicologia \& Sociedade, 17(3), 42-49.

Dadico, L., \& Souza, M. P. R. (2010). Atuação do psicólogo em organizações não-governamentais na área da educação. Psicologia, Ciência e Profissão, 30(1), 114-131.

Donzelot, J. (2001). A polícia das famílias. Rio de Janeiro: Graal.

Eidelwein, K. (2007). Psicologia social e serviço social: uma relação interdisciplinar na direção da produção de conhecimento. Textos \& Contextos, 6(2), 298-313.

Elia, L. (2004). O conceito de sujeito lacaniano. Rio de Janeiro: Jorge Zahar.

Ferreira, C. R. C. (2010). As contribuições da psicologia histórico- cultural aos psicólogos que trabalham junto às políticas públicas de assistência social voltadas às crianças entrezero e seis (Dissertação de mestrado não-publicada). Programa de Pós-Graduação em Psicologia, Universidade Estadual de Maringá.

Fink, B. (1998). O sujeito lacaniano: entre a linguagem eo gozo. Rio de Janeiro: Jorge Zahar.

Fontenele, A. F. G. T. (2008). Psicologia e Sistema Único de Assistência Social-SUAS:estudo sobrea inserção de psicólogos nos Centros de Referência da Assistência Social - CRAS (Dissertação de mestrado não-publicada). Programa de Pós-Graduação em Psicologia Social, Universidade Federal do Ceará.

Foucault, M. (1999). Vigiar e punir: nascimento da prisão. Petrópolis: Vozes.

Garcia-Roza, L. A. (2009). Freude o inconsciente. Rio de Janeiro: Jorge Zahar.

Goffman, E. (1987). Manicômios, prisões econventos. São Paulo: Perspectiva.

Gonçalves, M. G. M. (2010). Psicologia, subjetividade e políticas públicas. São Paulo: Cortez.

Heidegger, M. (1995). Ser e tempo. Petrópolis: Vozes.

Lacan, J. (1979). Oseminário: os quatro conceitos fundamentais da psicanálise: Livro 11. Rio de Janeiro: Jorge Zahar.

Lacan, J. (1998). Escritos. Rio de Janeiro: Jorge Zahar.

Lancetti, A. (Org.). (1996). Assistência social e cidadania: invenções, tensões e construção da experiência de Santos. São Paulo: Hucitec. 
Lemos, F. C. S. (2007). Crianças e adolescentes entre a norma e a lei: uma análise foucaultiana. (Tese de doutorado não-publicada). Programa de Pós-Graduação em História e Sociedade, Universidade Estadual Paulista.

Lourau, R. (1995). A análise institucional. Petrópolis: Vozes.

Marx, K. (1978). Manuscritos econômicos e filosóficos (1844) e outros textos escolhidos. São Paulo: Abril Cultural.

Montaño, C. E. (2007). Terceiro setor e questão social: crítica ao padrão emergente de intervenção social. São Paulo: Cortez.

Murta, S. G., \& Marinho, T. P. C. M. (2009). A clínica ampliada e as políticas de Assistência Social: uma experiência com adolescentes no Programa de Atenção Integral à Família. Revista Eletrônica de Psicologia e Políticas Públicas, 1(1). Recuperado em julho, 2010, disponível em: <http:// www.crp09.org.br>.

Olgivie, B. (1988). Lacan: a formação do conceito de sujeito (1931-1949). Rio de Janeiro: Jorge Zahar.

Paiva, I. L., \& Yamamoto, O. H. (2010). Formação e prática comunitária do psicólogo no âmbito do "terceiro setor". Estudos de Psicologia (Natal),15(2), 153-160.

Patto, M. H. S. (1990). A produção do fracasso escolar. São Paulo: T.A. Queiróz.

Pontual, P., \& Ireland, T. (Orgs.). (2006). Educação popular na América Latina: diálogos e perspectivas. Brasília: MEC.

Rodrigues, M. M. A. (2010). Políticas públicas. São Paulo: Publifolha.

Rogone, H. M. H. (2006). Psicanálise e cidadania: correndo riscos e tecendo laços (Tese de doutorado não-publicada). Programa de Pós-Graduação em Psicologia Escolar e do Desenvolvimento Humano, Universidade de São Paulo.

Saliba, M. G. (2006). Oolho do poder: análise crítica da proposta educativa do Estatuto da Criança e do Adolescente. São Paulo: Unesp.

Santana, J. P., Doninelli, T. M., Frosi, R. V., \& Koller, S. H. (2004). Instituições de atendimento a crianças e adolescentes em situação de rua. Psicologia \& Sociedade, 16(2), 59-70.
Scarparo, M. L. D. E. (2008). Em busca do sujeito perdido: a psicanálise na Assistência Social, limites e possibilidades (Dissertação de mestrado não-publicada). Programa de Pós-Graduação em Psicologia Social e Institucional, Universidade Federal do Rio Grande do Sul.

Senra, C. M. G. (2009). Psicólogos sociais em uma instituição pública de Assistência Social: analisando estratégias de enfrentamento (Tese de doutorado não-publicada). Programa de Pós-Graduação em Psicologia, Pontifícia Universidade Católica de Campinas.

Silva, G. H. (2008). A construção da identidade do educador social na sua prática cotidiana: a pluralidade de um sujeito singular (Dissertação de mestrado não-publicada). Programa de Pós-Graduação em Educação, Universidade de São Paulo.

Silveira, A. F., Cobalchini, C. C. B., Menz, D. M., Valle, G. A., \& Barbarini, N. (2007). Caderno de psicologia e políticas públicas. Curitiba: CRP.

Valas, P. (2001). As dimensões do gozo. Rio de Janeiro: Jorge Zahar.

Vallejo, A., \& Magalhães, L. C. (1979). Lacan: operadores de leitura. São Paulo: Perspectiva.

Vasconcelos, E. M. (2008a). Abordagens psicossociais: história, teoria e trabalho no campo. São Paulo: Hucitec.

Vasconcelos, E. M. (Org.). (2008b). Abordagens psicossociais: reforma psiquiátrica esaúde mental na ótica da cultura e das lutas populares. São Paulo: Hucitec.

Vasconcelos, E. M. (2009). Abordagens psicossociais: perspectivas para o serviço social. São Paulo: Hucitec.

Zaniani, E. J. M. (2008). Sob os auspícios da proteção: Moncorvo Filho e a higienização da infância (Dissertação de mestrado não-publicada). Programa de Pós-Graduação em Psicologia, Universidade Estadual de Maringá.

Recebido em: 21/11/2011

Aprovado em: 16/2/2012 
